\title{
The Home Accident Cases Applying to The Pediatric Emergency Department during the Covid-19 Pandemic: What Did the Pandemic Change?
}

\author{
Okşan Güleryüz ${ }^{1}$, Ozlem Colak ${ }^{1}$, Songul Tomar Güneysu², and İlknur FİDANCI ${ }^{3}$ \\ ${ }^{1}$ Affiliation not available \\ ${ }^{2}$ Gazi University \\ ${ }^{3}$ Ankara Education and Research Hospital
}

February 13, 2021

\begin{abstract}
Background: Whether the pandemic caused an increase in the number of home accidents (HA) admitted to the pediatric emergency department (PED) was investigated. Applications in a similar quarter in 2019 and 2020 were compared. Methods: The study was retrospective. Their demographic data, the reason for admission to the hospital, the time of admission, the length of hospital stay, intensive care rate, and interventional procedures were recorded. The two groups were compared to find whether there was any difference. Results: There were 700 and 597 admissions for specified reasons during the specified period in 2019 and 2020, respectively. In 2019, 9.46\% of all cases admitted to the PED were HA whereas the rate was $24.43 \%$ in 2020 . The male/female ratios were similar $(\mathrm{p}=0.520)$. The median age in 2020 (36 months) was significantly higher than that in 2019 (33 months) $(\mathrm{p}=0.010)$. The main clinical presentations also differed significantly. The incidence of falls, the gastric/intestinal foreign bodies, and the penetrating stab injuries were significantly higher in those in $2020(\mathrm{p}<0.001)$. Significant differences were also found regarding diagnostic and therapeutic interventions. During the specified period in 2019, 623 patients (89.5\%) were discharged from the PED. The rate of discharge in 2020 (84.9\%) was significantly lower. Also, there were significantly more hospitalizations in other wards in 2020 than those in 2019 (3.7\% vs. 1.0\%) ( $\mathrm{p}=0.004)$. Conclusion: The Covid-19 pandemic caused an increase in the number of HAs cases admitted to the PED relative to all hospital admissions. The most common type of accident was falls, as in the non-pandemic period. The pandemic caused delays in accessing healthcare services, especially for critically ill patients, more frequent hospitalizations, and a decrease in the rate of discharge from the PED.
\end{abstract}

The home accident cases applying to the pediatric emergency department during the Covid-19 pandemic: what did the pandemic change?

Oksan Derinoz-Guleryuz ${ }^{\mathrm{a}}$, Ozlem Colak ${ }^{\mathrm{a}}$, Songul Tomar ${ }^{\mathrm{a}}$, Ilknur Fidanc1 $^{\mathrm{a}}$

${ }^{a}$ Department of Pediatric Emergency, Gazi University Faculty of Medicine, Ankara, Turkey

Running Title: Home accidents in the Covid-19 pandemic

Corresponding Author:

Oksan Derinoz-Guleryuz, MD

Department of Pediatric Emergency, Gazi University, Faculty of Medicine, Ankara, Turkey

E-mail: oderinoz@gazi.edu.tr,oksan197@yahoo.com

Phone: +90 3122024212 
ORCID: 0000-0001-7348-0656

\section{Disclosures}

Oksan Derinoz-Guleryuz declares that she has no conflict of interest concerning the research, authorship or publication of this article.

Ozlem Colak declares that she has no conflict of interest concerning the research, authorship or publication of this article.

Songul Tomar-Guneysu declares that she has no conflict of interest concerning the research, authorship or publication of this article.

Ilknur Fidanci declares that she has no conflict of interest concerning the research, authorship or publication of this article.

The home accident cases applying to the pediatric emergency department during the Covid-19 pandemic: what did the pandemic change?

\section{Abstract:}

Background: Whether the pandemic caused an increase in the number of home accidents (HA) admitted to the pediatric emergency department (PED) was investigated. Applications in a similar quarter in 2019 and 2020 were compared.

Methods: The study was retrospective. Their demographic data, the reason for admission to the hospital, the time of admission, the length of hospital stay, intensive care rate, and interventional procedures were recorded. The two groups were compared to find whether there was any difference.

Results: There were 700 and 597 admissions for specified reasons during the specified period in 2019 and 2020 , respectively. In $2019,9.46 \%$ of all cases admitted to the PED were HA whereas the rate was $24.43 \%$ in 2020. The male/female ratios were similar ( $\mathrm{p}=0.520)$. The median age in 2020 (36 months) was significantly higher than that in 2019 (33 months) ( $\mathrm{p}=0.010)$. The main clinical presentations also differed significantly. The incidence of falls, the gastric/intestinal foreign bodies, and the penetrating stab injuries were significantly higher in those in $2020(\mathrm{p}<0.001)$. Significant differences were also found regarding diagnostic and therapeutic interventions. During the specified period in 2019,623 patients $(89.5 \%)$ were discharged from the PED. The rate of discharge in 2020 (84.9\%) was significantly lower. Also, there were significantly more hospitalizations in other wards in 2020 than those in 2019 (3.7\% vs. 1.0\%) ( $\mathrm{p}=0.004)$.

Conclusion: The Covid-19 pandemic caused an increase in the number of HAs cases admitted to the PED relative to all hospital admissions. The most common type of accident was falls, as in the non-pandemic period. The pandemic caused delays in accessing healthcare services, especially for critically ill patients, more frequent hospitalizations, and a decrease in the rate of discharge from the PED.

Keywords: children, Covid-19, home accidents, pediatric emergency department

\section{What is known?}

Home accidents are one of the most important causes of mortality and morbidity, especially in preschool children.

Home accidents constitute a significant part of emergency department admissions.

\section{What is new?}

- The Covid-19 pandemic has increased the incidence of home accidents.

- One-fourth of cases admitted to the pediatric emergency in the pandemic period in 2020 were home accidents, which was one-tenth in 2019.

- Falls, foreign body ingestions, penetrating stab injuries, and cuts were more common during the pandemic period. 
- The pandemic resulted in more cases to be hospitalized for treatment, and the rate of discharge from the emergency department decreased.

The home accident cases applying to the pediatric emergency department during the Covid-19 pandemic: what did the pandemic change?

\section{Introduction:}

A new type of coronavirus called pneumonia-associated SARS-CoV-2 (Severe Acute Respiratory Distress Syndrome Coronavirus 2) was reported for the first time in Wuhan in Hubei Province of China in late December 2019. In the following weeks, the virus spread to all parts of China, and to the whole world afterwards. The World Health Organization (WHO) declared the outbreak a Public Health Emergency of International Concern on January 30, 2020, named the disease as coronavirus disease 2019 (Covid-19) on February 12, 2020, and declared a pandemic on March 11, 2020. ${ }^{1}$

The first case in Turkey was reported on March 10, 2020, and since then, measures were introduced to limit the spread of the disease in local communities by preventing people from forming crowded groups. In this context, the first measure was closing educational institutions starting from March 16, 2020, until an unspecified date. Later, the restrictions were further expanded with the "stay at home" orders and by banning children and adolescents under 20 from leaving home after April 4, 2020. As a result of these restrictions, children whose living areas were limited to homes started to come to the emergency departments due to home accidents during their stay at home, mainly due to delayed applications.

The home accidents are among the most common causes of mortality and morbidity in children and constitute a substantial part of admissions to emergency departments. Falls, burns, poisoning, and related complications are common in accidents at or around home. Although the home accidents are seen in all age groups, they are especially a significant problem for children and the elderly, with increased mortality and morbidity. ${ }^{2}$

This study aimed to determine whether there was an increase in the number of the home accidents admitted to emergency departments because children and adolescents under 18 were subject to stay at home orders during the pandemic.

\section{Materials and Method:}

The study was conducted at a university pediatric emergency department (PED) that provides tertiary healthcare services. The home accident cases that presented to our PED within the three-month period from March 11, 2020 to June 10, 2020 were recorded in the data form. The home accident cases in the same period in 2019 were also recorded and investigated retrospectively.

For the cases that presented in these periods, the demographic data, the reason for admission to the hospital, the time of admission, the length of hospital stay, the rate of intensive care, and the interventional procedures (endoscopy, bronchoscopy, surgery, etc.) were recorded. The two groups were compared in order to find any difference between two groups.

Household accidents were classified as falls, poisoning (with drugs and non-drug substances), caustic/corrosive ingestion, foreign body ingestion or aspiration, stab injuries, suffocation, and burns. Considering the age groups where the home accidents were common, the patients were divided into two groups as [?]5 or $>5$ years old.

Life-saving interventions, including bag-valve-mask (BVM) ventilation, intubation, surgical airway, continuous positive airway pressure (CPAP), bilevel positive airway pressure (BiPAP), defibrillation, cardioversion, external pacing, needle thoracostomy, pericardiocentesis, thoracotomy, intraosseous intervention, marked fluid resuscitation, blood transfusion, major bleeding control, and the use of naloxone, dopamine, atropine, or $50 \%$ dextrose, were also determined and recorded in the data form according to the Emergency Severity Index (ESI). ${ }^{3}$

Ethical approval 
The approval was obtained from the local ethics committee before the study (dated 06.06.2020, numbered $6)$.

\section{Statistical analysis}

Descriptive statistics were given as mean \pm standard deviation or median [minimum-maximum] for continuous variables depending on their distribution. Numbers and percentages were used for categorical variables. The normal distribution of the numerical variables was analyzed by the Kolmogorov-Smirnov test and checked by Q-Q plots and histograms.

In comparing two independent groups, the Mann-Whitney U test was applied for variables without normal distribution. Pearson chi-square and Fisher's exact tests were used in $2 \times 2$ tables to compare the differences regarding categorical variables. Statistical analyses were performed with Jamovi (version 1.6.3, retrieved from https://www.jamovi.org) and JASP (version 0.13.1, retrieved from https://jasp-stats.org). The significance level (p-value) was set at 0.05 in all statistical analyses.

\section{Results:}

There were 700 and 597 pediatric admissions during the specified periods of 2019 and 2020, respectively. The demographic and clinical characteristics of the patients were summarized in Table 1 . In 2019, 9.46\% of the cases admitted to the emergency department were home accidents; this rate was $24.43 \%$ in 2020 . The ratio of female and male patients was similar in both periods $(\mathrm{p}=0.520)$. The median age of the children admitted in 2020 was significantly higher than that in 2019 (36 months vs. 33 months) ( $\mathrm{p}=0.010)$. The children aged [?]5 were more commonly admitted in both periods $(\mathrm{p}=0.463)$. The rate of the patients referred from an initial receiving hospital significantly increased from $10.5 \%$ in 2019 to $18.4 \%$ in $2020(\mathrm{p}<0.001)$. Emergency medical services were used significantly and more frequently for these patients in $2020(\mathrm{p}=0.011)$. A comparison of monthly admissions between 2019 and 2020 revealed that there was no significant difference between the admissions during 11-31 March in 2019 and 2020, but the percentage of the patients admitted during April 2020 was higher than those in April 2019 (38.5 \% vs. 25.3\%). The rates in May or 1-10 June in 2020 were significantly lower than those in $2019(\mathrm{p}<0.001)$. There was no significant difference between the groups in terms of the time of admission and the time to hospital admission ( $\mathrm{p}=0.732$ and $\mathrm{p}=0.147$, respectively).

The main clinical presentations showed significant differences between the groups. The proportion of falls, gastric/intestinal foreign bodies, and penetrating stab injuries were significantly higher in 2020 ( $p<0.001)$.

Significant differences were found between the groups regarding the diagnostic and therapeutic interventions as well. (Table 2). Although minor surgical procedures were the most common treatment procedures in both groups, they were more frequently performed in $2020(\mathrm{p}<0.001)$. There were no significant differences between the groups regarding the type of urgency, the ESI triage categories, the Glasgow Coma Scale (GCS) scores at the admission, and the type of poisoning ( $>0.05)$.

ESI resource utilization was homogenous in 2019, and significant differences were found between those admitted in 2019 and 2020 regarding resource utilization. A significantly lower proportion of the patients $(16.2 \%)$ required no resource utilization in 2020 , compared to $30.8 \%$ in 2019 . Those requiring more than one source were significantly more in 2020.

A total of 623 patients $(89.5 \%)$ were discharged from the emergency department during the study period in 2019, which was significantly higher than the rate of discharge in 2020 (84.9\%). A significantly higher proportion of the patients was hospitalized in other wards in 2020 than in 2019 (3.7\% vs. 1.0\%) ( $\mathrm{p}=0.004)$.

A comparison of demographic and clinical characteristics of the cases based on the date of admission was shown in Table 3. The proportion of female patients was significantly higher during the period of May 1 to June $10(\mathrm{p}=0.015)$. The proportion of female patients increased progressively from $35.0 \%$ to 52.65 during the study period. The median age of the patients was significantly lower in this period compared to those in the period of March 11 to April 30 ( $\mathrm{p}=0.023$ ). The majority of the admissions occurred between 4 PM and 0 AM. A significant difference was found in the distribution of admission time in different months $(\mathrm{p}=0.029)$ 
(Table 3). However, the admission status, the type of admission, the time to hospital admission after the event, and the distribution of the main clinical presentations were similar in the patients admitted in different months $(\mathrm{p}>0.05)$.

The distributions of main clinical presentation in two age groups in 2019 and 2020 were shown in Table 4. In both periods, the most common reason for visiting the emergency room was falls in those under five years. Significant differences were found between the age groups regarding the complaints at admission in both years $(\mathrm{p}<0.001$ for both).

\section{Discussions:}

The home accidents are the leading preventable accidents in Turkey and in the world. ${ }^{4}$ They are frequently seen in the preschool period, leading to disabilities or even death. According to the WHO data, burns, falls, and poisoning are the most common accidents in children younger than 15 and this forms one of the most significant health problems. Previous studies have reported that $18-40 \%$ of all accidents in Turkey were the home accidents. ${ }^{5,6}$

There is a great deal of responsibility for those who care for children in preventing the home accidents. Considering that preschool-age groups spend more time at home, the home environments should be made safer for this age group. The human factor is critical in the emergence of accidents. Lack of knowledge, negligence, or recklessness is the leading cause of such accidents. Environmental factors (such as building, furniture, or toy safety) also contribute to the home accidents. However, the contribution of global pandemics to the emergence of home accidents is not known.

Since respiratory droplets have been reported to be the transmission route for the disease caused by SARSCoV-2 (Covid-19), which started at the end of 2019 and spread all over the world in a short period, a number of restrictive measures have been taken in order to prevent crowding and the spread of the disease in communities. The first measure in Turkey was closing educational institutions on March 16, 2020, and moving educational activities to online medium until an unspecified date. Subsequently, the restrictions were further expanded after April 4, 2020, with "stay at home" orders and curfews for children and adolescents under 20. These restrictions resulted in children and adolescents spending more time at home.

In this period of uncertainties, changes were introduced in the delivery of emergency healthcare services. The number of the patients admitted to the PEDs has decreased in time considerably. It was also noticed that most of the patients came to the hospital with severe clinical conditions. In this context, we analyzed the impact of the "stay at home" orders with respect to the admissions to PEDs due to the home accidents. Our study indicated that the number of the patients admitted to our PED due to the home accidents during the pandemic period (March - June 2020) was lower than that in the same period of 2019. However, one-fourth of all admissions to the PED were due to the home accidents in this period of 2020 while only one-tenth of all admissions were due to the home accidents in the same period of 2019. In addition, the female/male ratios were similar; the patients in 2020 benefited more from emergency services; falls, foreign bodies in the stomach/intestines, penetrating stab injuries, and cuts were more common in 2020; and there were differences between these periods regarding the diagnostic and the therapeutic procedures. It was also found that the proportion of hospitalized patients was higher in 2020, and these patients were less frequently discharged from the emergency room.

Several studies have demonstrated that the type of the home accidents varied by age. Falls and crashes are the most common types of the home accidents and more frequent in children under the age of five..$^{7,8-12}$ Falls constitute approximately $30 \%$ of trauma admissions and $15 \%$ of emergency room admissions ${ }^{13}$ and are especially common in boys and children under five. ${ }^{14,15-18}$ Foreign bodies in the esophagus and other parts of the gastrointestinal system are frequent in children between six months and three years. Mortality due to foreign body ingestion is very low. ${ }^{19-23}$ In our study, falls were the most common reason for emergency room admissions in the studied period of 2019 and 2020. In our study, falls were more common in children aged five or younger. Falls, foreign bodies in the stomach/intestines, penetrating stab injuries were more common in 2020 than in 2019. The number of admissions to the emergency room was highest in April. Falls were the 
most common reason for visiting the emergency room in all months of the studied period. A previous study has shown that falls were the most common complaint in all months [24].

Studies have shown that boys are more prone to accidents because they are more active and adventurous than girls. ${ }^{25-27}$ On the contrary, our study indicated that girls and boys involved in the home accidents were comparable. However, more girls were admitted between May 1 and June 10, and the proportion of girls admitted to the emergency room increased almost two-folds during the study.

It was interesting that the number of applications for emergency care was highest between 16:00 and 24:00. With the "stay at home" orders, many institutions implemented flexible or remote working; therefore, a significant portion of the caregivers spent more time at home with their children. It was surprising that the applications to the emergency room were often during these hours.

The rates of recovery or sequelae after home accidents have been reported between $7.8 \%$ and $18 \%$. Mortality rates were reported to be between $0 \%$ and $2 \% .{ }^{12,28,29}$ In our study, approximately $90 \%$ of the cases in 2019 and approximately $85 \%$ of the cases in 2020 were discharged from the emergency room without any sequelae. However, it was found that the cases in 2020 required more hospitalization and intensive care compared to the previous year. This was thought to result from the late admission of these cases or more serious type of accidents and injuries. When all cases were considered, most of the cases presented to the emergency department within the first three hours of the accident. Of three patients, who received intensive care, two had ingested button batteries; one of the patients (10 months old) had melena for three days; the other two patients were admitted to the hospital within three hours of ingesting drugs. The length of hospital stay was similar in both years.

\section{Conclusion:}

Our study is the first to reveal the impact on emergency services by the home accidents involving children during the "stay at home" period because of the global epidemic. The pandemic resulted in an increase in the proportion of the home accidents in all admissions to the emergency room. The most common type of accident was falls, as in the previous periods. The pandemic caused delays in accessing health services, especially in critical patients, more hospitalizations for treatment, and a decreased discharge rate from the emergency department.

\section{Acknowledgements:}

Authorship: Dr. Derinoz-Guleryuz and at all.conceptualized and designed the study, coordinated and supervised data collection, and critically reviewed the manuscript for important intellectual content.

Funding : The author(s) received no financial support for the research, authorship, and/or publication of this article.

Availability of data and materials : Research data can be obtained upon request.

Ethics Committee Approval Status: Reviewed and approved by the Ethics Committee of Gazi University.

\section{References:}

1. Zu ZY, Jiang MD, Xu PP, Chen W, Ni QQ, Lu GM, et al. Coronavirus disease 2019 (COVID-19): a perspective from China. Radiology2020;21:200490.

2. Altuntaş M, Kaya M, Demir Ş, Oyman G, Metecan A, Rastgel H, et al. 0-14 Yaş arası çocuklarda önlenebilir nitelikteki kazaların belirlenmesi ve ilişkili tedbirlerin alınması. Smyrna Tıp Dergisi $2013 ; 1 ; 28-33$.

3. Gilboy N, Tanabe T, Travers D, Rosenau AM. Emergency Severity Index (ESI): A triage tool for emergency department. Rockville, MD: Agency for Healthcare Research and Quality; 2011.

4. Yanchar NL, Warda LJ, Fuselli P, Canadian Paediatric Society, Injury Prevention Committee. Child and youth injury prevention: A public health approach. Paediatr Child Health 2012;17(9):511. 
5. Baysal S, Birinci A. Childhood injuries and injury control. Türkiye Klinikleri J Pediatr Sci 2006;2:64-78.

6. Kurt FY, Aytekin A. Home accidents in children aged 0-6 years.J Health Sci Profession-HSP 2015;2:2232.

7. Karatepe T U, Akış N. The frequency of having home accident among 0-6 aged children and related factors. Uludă̈ Üniv Tip Fak Derg2013;39:165-8.

8. Aggarwal R, Singh API, Aditya K. Pattern of domestic injuries in a rural area of India. Internet $J$ Health 2009;11:1-6.

9. Ahuja RB, Bhattacharya S. An analysis of 11.196 burn admissions and evaluation of conservative management techniques. Burns 2002;2:555-61.

10. Alptekin F, Uskun E, Kisioglu AN, Ozturk M. Unintentional nonfatal home-related injuries in Central Anatolia, Turkey: frequencies, characteristics, and outcome. Injury 2008;39:536-46.

11. Matantire DN, Nsungu M, Mabhiza ET. Factors associated with incidence of domestic accidents in children aged 0-5 years is Chikomba District, Mashonaland East, Zimbabwe. Cent Afr J Med1994;40;1139 .

12. Bhanderi DJ, Choudhary S. A Study of occurrence of domestic accidents in semi-urban community. Indian J Community Med2008;33;2:104-6.

13. Scuffham P, Chaplin S, Legood R. Incidence and costs of unintentional falls in older people in the United Kingdom. J Epidemiol Community Health 2003;57:740-4.

14. Laraque D, Barlow B, Durkin M. Prevention of youth injuries. Natl Med Assoc 1999;91(10):557-71.

15. Kocak S, Dundar ZD, Yavuz K, Onal MA, Dikmetas C, Girisgin AS, et al. Etiologic factors in falls from height in pediatric cases. Eur J Trauma Emerg Surg 2012;38(3):313-7.

16. Pressley JC, Barlow B. Child and adolescent injury as a result of falls from buildings and structures. Inj Prev 2005;11:267-73.

17. Babu A, Rattan A, Ranjan P, Singhal M, Gupta A, Kumar S, et al. Are falls more common than road traffic accidents in pediatric trauma? Experience from a Level 1 trauma centre in New Delhi, India. Chin J Traumatol 2016;19(2):75-8.

18. MacInnes K, Stone DH. Stages of development and injury: An epidemiological survey of young children presenting to an emergency department. BMC Public Health 2008;8:120.

19. Wyllie R. Foreign bodies in the gastrointestinal tract. Curr Opin Pediatr 2006;18(5):563.

20. Uyemura MC. Foreign body ingestion in children. Am Fam Physician . 2005;72(2):287.

21. Banerjee R, Rao GV, Sriram PV, Reddy KS, Nageshwar Reddy D. Button battery ingestion. Indian $J$ Pediatr 2005;72(2):173.

22. Simic MA, Budakov BM. Fatal upper esophageal hemorrhage caused by a previously ingested chicken bone: case report. Am J Forensic Med Pathol 1998;19(2):166.

23. Yardeni D, Yardeni H, Coran AG, Golladay ES. Severe esophageal damage due to button battery ingestion: can it be prevented? Pediatr Surg Int 2004;20(7):496.

24. Rumhi AA, Al Awisi H, Al Buwaiqi M, Al Rabaani S. Home accidents among children: a retrospective study at a tertiary care center in Oman. Oman Med $J$ 2020;35(1):e85.

25. Grivna M, Barss P, Stanculescu C, Eid HO, Abu-Zidan FM. Child and youth traffic-related injuries: use of a trauma registry to identify priorities for prevention in the United Arab Emirates. Traffic Inj Prev 2013;14(3):274-82.

26. Eldosoky RS. Home-related injuries among children: knowledge, attitudes and practice about first aid among rural mothers. East Mediterr Health J 2012;18(10):1021-7.

27. Broides A, Assaf M. Home accidents in Arab Bedouin children in southern Israel. J Child Health Care 2003;7(3):207-14.

28. Olawale OA, Owoaje ET. Incidence and pattern of injuries among residents of a rural area in South Western Nigeria: a community-based study. BMC Public Health 2007;7:246.

29. Neghab M, Rajaei Fard A, Habibi M, Choobineh A. Home accidents in rural and urban areas of Shiraz, 2002. East Mediterr Health J2006;12:824-33.

Tables: 
Table 1. Demographic and clinical features of the study groups.

\begin{tabular}{|c|c|c|c|}
\hline Variable $^{+}$ & $2019(n=700)$ & $2020(n=597)$ & $\mathbf{p}$ \\
\hline \multicolumn{4}{|l|}{ Sex } \\
\hline Female & $329(47.0)$ & $269(45.1)$ & 0.520 \\
\hline Male & $371(53.0)$ & $328(54.9)$ & \\
\hline Age (month) & $33.0[1.0-213.0]$ & $36.0[2.0-267.0]$ & 0.010 \\
\hline \multicolumn{4}{|l|}{ Age $^{+}$} \\
\hline [?]5 years & $502(71.7)$ & $417(69.8)$ & 0.463 \\
\hline$>5$ years & $198(28.3)$ & $180(30.2)$ & \\
\hline \multicolumn{4}{|l|}{ Date of admission } \\
\hline March & $163(23.3)$ & $140(23.5)$ & $<0.001$ \\
\hline April & $177(25.3)^{*}$ & $229(38.5)^{*}$ & \\
\hline May & $267(38.1)^{*}$ & $169(28.4)^{*}$ & \\
\hline June & $93(13.3)^{*}$ & $57(9.6)^{*}$ & \\
\hline \multicolumn{4}{|l|}{ Time of admission } \\
\hline 08:00 - 16:00 & $214(30.6)$ & $181(30.8)$ & 0.732 \\
\hline $16: 00-24: 00$ & $390(55.7)$ & $335(57.0)$ & \\
\hline $24: 00-08: 00$ & $96(13.7)$ & $72(12.2)$ & \\
\hline \multicolumn{4}{|l|}{ Admission status } \\
\hline Referred & $73(10.5)$ & $109(18.4)$ & $<0.001$ \\
\hline Direct admission & $620(89.5)$ & $483(81.6)$ & \\
\hline \multicolumn{4}{|l|}{ Type of admission } \\
\hline Self-presented & $680(97.1)$ & $560(94.1)$ & 0.011 \\
\hline EMS & $20(2.9)$ & $35(5.9)$ & \\
\hline \multicolumn{4}{|l|}{$\begin{array}{l}\text { Time to hospital } \\
\text { admission }\end{array}$} \\
\hline 1 hour & $306(51.7)$ & $311(56.2)$ & 0.147 \\
\hline 1-3 hours & $155(26.2)$ & $127(23.0)$ & \\
\hline 3-6 hours & $32(5.4)$ & $42(7.6)$ & \\
\hline 6-12 hours & $36(6.1)$ & $26(4.7)$ & \\
\hline$>12$ hours & $63(10.6)$ & $47(8.5)$ & \\
\hline \multicolumn{4}{|l|}{$\begin{array}{l}\text { Main clinical } \\
\text { presentation }\end{array}$} \\
\hline Falls & $422(60.4)^{*}$ & $406(68.0)^{*}$ & $<0.001$ \\
\hline Poisoning - drugs & $34(4.9)$ & $17(2.8)$ & \\
\hline Poisoning - other & $3(0.4)$ & $4(0.7)$ & \\
\hline Ingestion of corrosives & $7(1.0)$ & $8(1.3)$ & \\
\hline Respiratory foreign body & $2(0.3)$ & $5(0.8)$ & \\
\hline Esophageal foreign body & $2(0.3)$ & $2(0.3)$ & \\
\hline $\begin{array}{l}\text { Gastrointestinal foreign } \\
\text { body }\end{array}$ & $22(3.1)^{*}$ & $8(1.3)^{*}$ & \\
\hline Penetrating stab injury & $35(5.0)^{*}$ & $55(9.2)^{*}$ & \\
\hline Others & $172(24.6)^{*}$ & $92(15.4)^{*}$ & \\
\hline
\end{tabular}

+ Data shown as n (\%) or median [min-max].

* Significant difference between the subgroups.

EMS: emergency medical services

Table 2. Comparison of diagnostic and therapeutic features concerning emergency service admissions, 
interventions and outcomes.

\begin{tabular}{|c|c|c|c|}
\hline Variable $^{+}$ & $2019(n=700)$ & $2020(n=597)$ & $\mathrm{p}$ \\
\hline \multicolumn{4}{|l|}{ Type of urgency } \\
\hline Minor urgency (green) & $0(0.0)^{*}$ & $8(1.3)^{*}$ & $<0.001$ \\
\hline Urgency (yellow) & $700(100.0)^{*}$ & $579(97.6)^{*}$ & \\
\hline Urgency (red) & $0(0.0)^{*}$ & $6(1.0)^{*}$ & \\
\hline GCS & $15.0[13.0-15.0]$ & $15.0[14.0-15.0]$ & 0.913 \\
\hline \multicolumn{4}{|l|}{ ESI } \\
\hline $\begin{array}{l}\text { ESI 1-2 } \\
\text { (resuscitation-emergent) }\end{array}$ & $0(0)$ & $2(0.3)$ & NA \\
\hline ESI 3 (urgent) & $0(0)$ & $264(44.2)$ & \\
\hline ESI 4 (less urgent) & $0(0)$ & $235(39.4)$ & \\
\hline ESI 5 (non-urgent) & $0(0)$ & $96(16.1)$ & \\
\hline \multicolumn{4}{|l|}{ Type of poisoning } \\
\hline Suicidal & $12(27.9)$ & $11(40.7)$ & 0.395 \\
\hline Accidental & $31(72.1)$ & $16(59.3)$ & \\
\hline \multicolumn{4}{|l|}{ Diagnostic } \\
\hline X-ray radiography & $271(38.7)$ & $148(24.8)$ & $<0.001$ \\
\hline Ultrasonography & $3(0.4)$ & $0(0.0)$ & 0.254 \\
\hline Computed tomography & $29(4.1)$ & $23(3.9)$ & 0.902 \\
\hline Biochemical analysis & $87(12.4)$ & $27(4.5)$ & $<0.001$ \\
\hline Electrocardiogram (\%) & $27(3.9)$ & $0(0.0)$ & $<0.001$ \\
\hline \multicolumn{4}{|l|}{$\begin{array}{l}\text { Therapeutic } \\
\text { interventions }\end{array}$} \\
\hline Observation only & $338(48.3)$ & $241(40.4)$ & 0.005 \\
\hline Intravenous hydration & $44(6.3)$ & $18(3.0)$ & 0.009 \\
\hline Gastric lavage & $9(1.3)$ & $0(0.0)$ & 0.005 \\
\hline Charcoal & $16(2.3)$ & $0(0.0)$ & 0.001 \\
\hline Antidote & $1(0.1)$ & $0(0.0)$ & 0.999 \\
\hline Endoscopy & $2(0.3)$ & $0(0.0)$ & 0.503 \\
\hline Minor surgical procedures & $176(25.1)$ & $253(42.4)$ & $<0.001$ \\
\hline $\begin{array}{l}\text { Major surgical } \\
\text { procedures }\end{array}$ & $1(0.1)$ & $5(0.8)$ & 0.100 \\
\hline Others & $0(0.0)$ & $6(1.0)$ & 0.009 \\
\hline \multicolumn{4}{|l|}{$\begin{array}{l}\text { ESI resource } \\
\text { utilization }\end{array}$} \\
\hline 0 & $215(30.8)^{*}$ & $97(16.2)^{*}$ & $<0.001$ \\
\hline 1 & $238(34.1)$ & $234(39.2)$ & \\
\hline$>1$ & $245(35.1)^{*}$ & $266(44.6)^{*}$ & \\
\hline \multicolumn{4}{|l|}{ Outcome } \\
\hline $\begin{array}{l}\text { Short-term observation in } \\
\text { ED }\end{array}$ & $64(9.2)$ & $65(10.9)$ & 0.004 \\
\hline $\begin{array}{l}\text { Hospitalization in } \\
\text { pediatric wards }\end{array}$ & $1(0.1)$ & $0(0.0)$ & \\
\hline Hospitalization in ICU & $1(0.1)$ & $3(0.5)$ & \\
\hline $\begin{array}{l}\text { Hospitalization in other } \\
\text { wards }\end{array}$ & $7(1.0)^{*}$ & $22(3.7)^{*}$ & \\
\hline Discharge & $623(89.5)^{*}$ & $505(84.9)^{*}$ & \\
\hline
\end{tabular}




\begin{tabular}{llll}
\hline Variable $^{+}$ & $\mathbf{2 0 1 9}(n=700)$ & $\mathbf{2 0 2 0}(n=597)$ & $\mathbf{p}$ \\
\hline $\begin{array}{l}\text { Length of hospital } \\
\text { stay (day) }\end{array}$ & $1.0[1.0-6.0]$ & $1.0[1.0-6.0]$ & 0.799 \\
\hline
\end{tabular}

+ Data shown as n (\%) or median [min-max].

* Significant difference between the subgroups.

ESI: Emergency Severity Index, GCS: Glasgow Coma Scale, ED: emergency department, ICU: intensive care unit

Table 3. Comparison of demographic and clinical characteristics of the admissions based on the admission month.

\begin{tabular}{|c|c|c|c|c|c|}
\hline & $\begin{array}{l}\text { Date of } \\
\text { admission }\end{array}$ & $\begin{array}{l}\text { Date of } \\
\text { admission }\end{array}$ & $\begin{array}{l}\text { Date of } \\
\text { admission }\end{array}$ & $\begin{array}{l}\text { Date of } \\
\text { admission }\end{array}$ & \\
\hline Variable $^{+}$ & $\begin{array}{l}\text { 11-31 March } \\
(\mathrm{n}=140)\end{array}$ & April $(n=229)$ & May $(\mathrm{n}=169)$ & $\begin{array}{l}\text { 1-10 June } \\
(\mathrm{n}=57)\end{array}$ & $\mathrm{p}$ \\
\hline \multicolumn{6}{|l|}{ Sex } \\
\hline Female & $49(35.0)$ & $102(44.5)$ & $88(52.1)$ & $30(52.6)$ & 0.015 \\
\hline Male & $91(65.0)$ & $127(55.5)$ & $81(47.9)$ & $27(47.4)$ & \\
\hline Age (month) & $\begin{array}{l}42.0[25.0- \\
74.5]\end{array}$ & $\begin{array}{l}36.0[21.0- \\
69.0]\end{array}$ & $\begin{array}{l}33.0[18.0- \\
66.0]\end{array}$ & $\begin{array}{l}33.0[17.0- \\
72.0]\end{array}$ & 0.023 \\
\hline \multicolumn{6}{|l|}{ Age } \\
\hline [?]5 years & $90(64.3)$ & $161(70.3)$ & $124(73.4)$ & $41(71.9)$ & 0.362 \\
\hline$>5$ years & $50(35.7)$ & $68(29.7)$ & $45(26.6)$ & $16(28.1)$ & \\
\hline \multicolumn{6}{|l|}{$\begin{array}{l}\text { Time of } \\
\text { admission }\end{array}$} \\
\hline 08:00 - 16:00 & $43(31.4)$ & $57(25.3)$ & $63(37.5)$ & $18(31.6)$ & 0.029 \\
\hline $16: 00-24: 00$ & $81(59.1)$ & $143(63.6)$ & $77(45.8)$ & $33(57.9)$ & \\
\hline $24: 00-08: 00$ & $13(9.5)$ & $25(11.1)$ & $28(16.7)$ & $6(10.5)$ & \\
\hline \multicolumn{6}{|l|}{$\begin{array}{l}\text { Admission } \\
\text { status }\end{array}$} \\
\hline Referred & $22(16.1)$ & $37(16.3)$ & $34(20.1)$ & $16(28.1)$ & 0.169 \\
\hline Direct admission & $115(83.9)$ & $190(83.7)$ & $135(79.9)$ & $41(71.9)$ & \\
\hline \multicolumn{6}{|l|}{$\begin{array}{l}\text { Type of } \\
\text { admission }\end{array}$} \\
\hline Self-presented & $133(95.0)$ & $214(93.9)$ & $154(91.7)$ & $57(100.0)$ & 0.100 \\
\hline EMS & $7(5.0)$ & $14(6.1)$ & $14(8.3)$ & $0(0.0)$ & \\
\hline \multicolumn{6}{|l|}{$\begin{array}{l}\text { Time to } \\
\text { hospital } \\
\text { admission }\end{array}$} \\
\hline 1 hour & $73(57.9)$ & $120(58.5)$ & $80(49.1)$ & $37(64.9)$ & 0.094 \\
\hline 1-3 hours & $26(20.6)$ & $44(21.5)$ & $49(30.1)$ & $7(12.3)$ & \\
\hline 3-6 hours & $8(6.3)$ & $16(7.8)$ & $15(9.2)$ & $3(5.3)$ & \\
\hline 6-12 hours & $8(6.3)$ & $9(4.4)$ & $3(1.8)$ & $6(10.5)$ & \\
\hline$>12$ hours & $11(8.7)$ & $16(7.8)$ & $16(9.8)$ & $4(7.0)$ & \\
\hline \multicolumn{6}{|l|}{$\begin{array}{l}\text { Main clinical } \\
\text { presentation }\end{array}$} \\
\hline Falls & $91(65.0)$ & $154(67.2)$ & $118(69.8)$ & $42(73.7)$ & 0.414 \\
\hline $\begin{array}{l}\text { Poisoning - } \\
\text { drugs }\end{array}$ & $7(5.0)$ & $3(1.3)$ & $6(3.6)$ & $1(1.8)$ & \\
\hline
\end{tabular}




\begin{tabular}{lllll}
\hline & $\begin{array}{l}\text { Date of } \\
\text { admission }\end{array}$ & $\begin{array}{l}\text { Date of } \\
\text { admission }\end{array}$ & $\begin{array}{l}\text { Date of } \\
\text { admission }\end{array}$ & $\begin{array}{l}\text { Date of } \\
\text { admission }\end{array}$ \\
\hline $\begin{array}{l}\text { Poisoning - other } \\
\begin{array}{l}\text { Ingestion of } \\
\text { corrosives }\end{array}\end{array}$ & $2(1.4)$ & $0(0.0)$ & $2(1.2)$ & $0(0.0)$ \\
$\begin{array}{l}\text { Respiratory } \\
\text { foreign body }\end{array}$ & $1(0.7)$ & $2(0.9)$ & $4(2.4)$ & $0(0.0)$ \\
$\begin{array}{l}\text { Esophageal } \\
\text { foreign body }\end{array}$ & $0(0.0)$ & $2(0.9)$ & $3(1.8)$ & $0(0.0)$ \\
$\begin{array}{l}\text { Gastrointestinal } \\
\text { foreign body }\end{array}$ & $2(1.4)$ & $5(2.2)$ & $0(0.0)$ & $0(0.0)$ \\
$\begin{array}{l}\text { Penetrating stab } \\
\text { injury }\end{array}$ & $11(7.9)$ & $27(11.8)$ & $14(8.3)$ & $1(1.8)$ \\
Others & $24(17.1)$ & $35(15.3)$ & $22(13.0)$ & $10(17.5)$ \\
\hline
\end{tabular}

+ Data shown as n (\%) or median [min-max].

EMS: emergency medical services

Table 4. Distribution of application complaints in both years by age groups.

\begin{tabular}{|c|c|c|c|}
\hline $\begin{array}{l}\text { Main clinical } \\
\text { presentation }^{+}\end{array}$ & [?] 5 years & $>5$ years & $\mathrm{p}$ \\
\hline $2019(n=700)$ & $(n=502)$ & $(n=198)$ & \\
\hline Falls & $335(66.9)^{*}$ & $87(43.9)^{*}$ & $<0.001$ \\
\hline Poisoning - drugs & $19(3.8)^{*}$ & $15(7.6)^{*}$ & \\
\hline Poisoning - other & $2(0.4)$ & $1(0.5)$ & \\
\hline Ingestion of corrosives & $7(1.4)$ & $0(0)$ & \\
\hline Respiratory foreign body & $2(0.4)$ & $0(0)$ & \\
\hline Esophageal foreign body & $0(0)^{*}$ & $2(1)^{*}$ & \\
\hline $\begin{array}{l}\text { Gastrointestinal foreign } \\
\text { body }\end{array}$ & $13(2.6)$ & $9(4.5)$ & \\
\hline Penetrating stab injury & $14(2.8)^{*}$ & $21(10.6)^{*}$ & \\
\hline Others & $109(21.8)^{*}$ & $63(31.8)^{*}$ & \\
\hline $2020(n=597)$ & $(n=417)$ & $(n=180)$ & \\
\hline Falls & $310(74.3)^{*}$ & $96(53.3)^{*}$ & $<0.001$ \\
\hline Poisoning - drugs & $8(1.9)^{*}$ & $9(5)^{*}$ & \\
\hline Poisoning - other & $2(0.5)$ & $2(1.1)$ & \\
\hline Ingestion of corrosives & $6(1.4)$ & $2(1.1)$ & \\
\hline Respiratory foreign body & $5(1.2)$ & $0(0)$ & \\
\hline Esophageal foreign body & $2(0.5)$ & $0(0)$ & \\
\hline $\begin{array}{l}\text { Gastrointestinal foreign } \\
\text { body }\end{array}$ & $6(1.4)$ & $2(1.1)$ & \\
\hline Penetrating stab injury & $16(3.8)^{*}$ & $39(21.7)^{*}$ & \\
\hline Others & $62(14.9)$ & $30(16.7)$ & \\
\hline
\end{tabular}

+ Data shown as n (\%).

* Significant difference between the subgroups. 